\title{
STUDIES OF FILLING, FLOODING AND EMPTYING PROCESSES OF INFILTRATION BASINS
}

\author{
Tkachuk O., Doctor of Engineering, Professor, \\ o.a.tkachuk@nuwm.edu.ua, ORCID: 0000-0002-3036-0010 \\ Yaruta Ya., post-graduate student, \\ ORCID: 0000-0001-9291-7710 \\ Shevchuk O., Ph.D., Assistant Lecturer, \\ ORCID: 0000-0002-7403-8314 \\ National University of Water and Environmental Engineering
}

\begin{abstract}
Paper shows that infiltration basins, served as regulating and filtering facilities in rainwater drainage systems, can operate in both flooded and submerged modes. As a result of experimental studies of an infiltration basin fragment with a typical vegetative top layer, it was established that the pressure loss almost completely falls on the upper base layer during the basins filling and emptying. At the same way the duration of their emptying depends on the parameters of basins base and the conditions of their emptying. The mathematical model of the operation of infiltration basins in the flooded mode has been refined and the ranges of changes in its additional parameters have been determined.
\end{abstract} filtration.

Keywords: drainage, regulation of storm water, infiltration basin, flooding, emptying,

Introduction. One of the effective controlling methods the flooding of urban areas is the regulation of rainwater runoff. Analysis of rainwater controlling methods showed that the most practical in urban conditions are filtration methods based on rain water retention directly in the places of precipitation [9-11], filtering in infiltration facilities, in particular infiltration basins with connection to drainage systems [8].

Analysis of previous studies. In Ukraine, the research of the rainwater accumulation in the bases for the rainwater regulation was carried out by such scientists Zhuk V.M. [1], Kachmar I.Z. [2], Popadyuk I.Yu. [3], Tkachuk O.A., Shevchuk O.V. [4-7] and others. However, none of these studies were conducted taking into account the work of these structures at their flood.

Previous studies of Shevchuk O.V. [7] showed that flooding of the improved infiltration area's pavement occurs at the rainwater intensity flow more than $i_{f l}=9 \mathrm{~mm} / \mathrm{min}$. However, the flooding process such a facility for pressure filtration has not been investigated. Such working conditions require clarification of the method of arrangement and calculation of rainwater drainage systems. Therefore, further research was oriented towards ensuring the rainwater intensity $i_{f l}>10 \mathrm{~mm} / \mathrm{min}$.

The purpose of the study is a study of the processes of filling, flooding and emptying of the infiltration basin with a typical upper vegetation layer on a pilot rig with flooding of the filling base layer and the pressure mode of rainwater filtration.

Method of the research. To study the filtration and accumulation processes of rainwater drains in the infiltration basins, an experimental installation (Fig. 1) was constructed, which is a fragment of an infiltration basin. Model sizes are $400 \times 600 \mathrm{~mm}$, a base height is $h_{l}=398 \mathrm{~mm}$, and the whole installation is $h=1000 \mathrm{~mm}$.

To provide vertical rainwater filtration through base course and its flow to drainage tube a small hydraulic resistant drainage at the bottom of the rig was constructed. It is arranged with gravel aggregate fractions of $20-25 \mathrm{~mm}$, with an average height of $20 \mathrm{~mm}$, covered with a mesh net. The drain tube is made of a $16 \mathrm{~mm}$ diameter metal-plastic pipe with slotted pores $1 \mathrm{~mm}$ wide by $1 / 3$ of the diameter of the tube per $10 \mathrm{~mm}$. Slits are turned towards drainage layer. 
The filling base of the installation is arranged in three layers: accumulative - from rubble fractions 10-25 mm, height $196 \mathrm{~mm}$; main sub-base course - gravel fractions $2.5-25 \mathrm{~mm}$, height $145 \mathrm{~mm}$; the bedding layer of sand with a fraction of $0.1-2 \mathrm{~mm}$ in thickness of $25 \mathrm{~mm}$, and soilvegetable layer (taken from the city roadsides) in a thickness of $28 \mathrm{~mm}$. All layers are separated with geotextiles with a density of $200 \mathrm{~g} / \mathrm{m}^{2}$ in thickness of $2 \mathrm{~mm}$. In the upper part of each base layer, piezometric tubes are installed to measure pressure losses and levels of water in in layers.

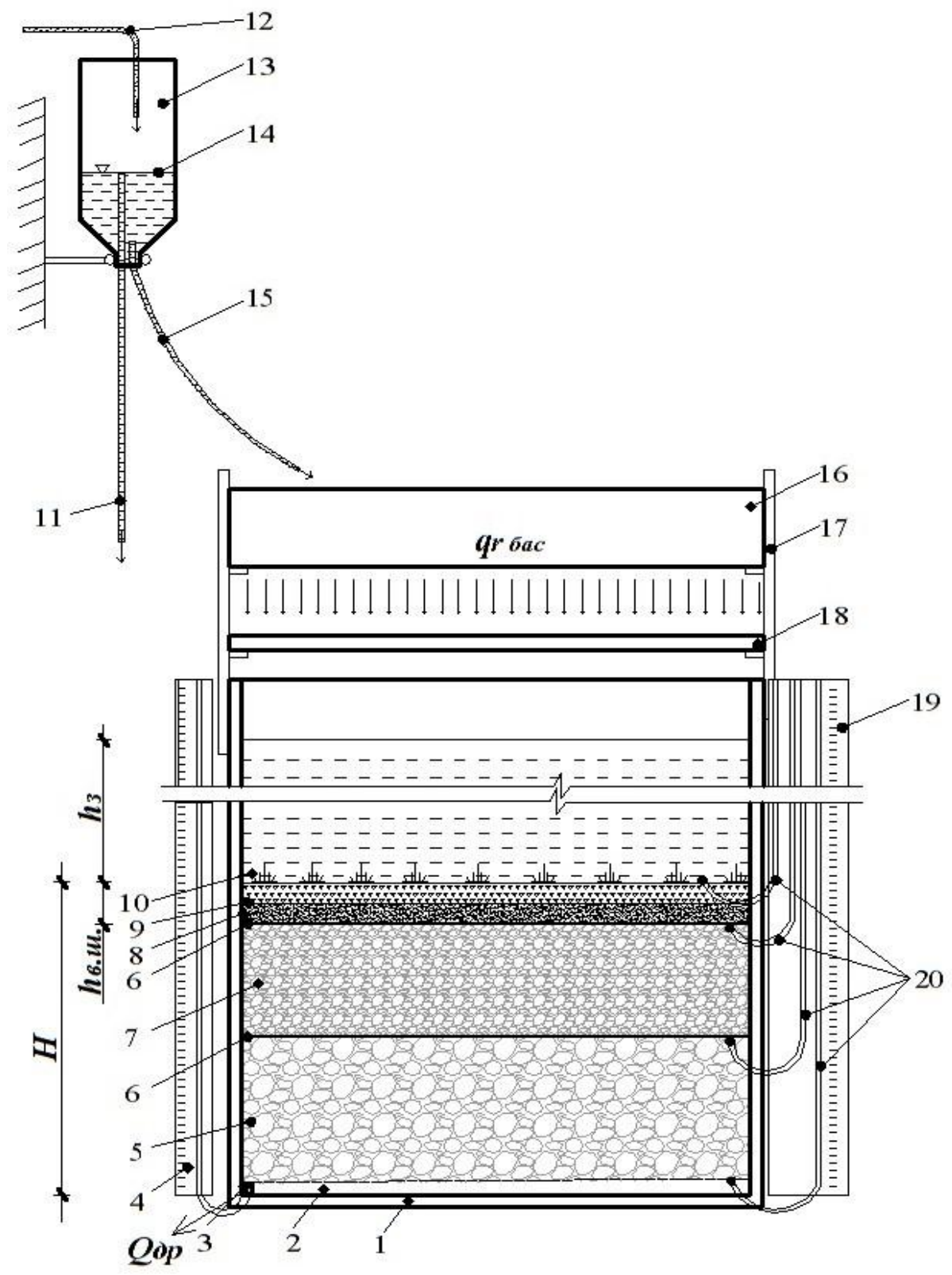

Fig.1. Scheme of experimental installation:

1 - frame of installation; 2 - drainage layer; 3 - drainage tube; 4 - control scale; 5 - accumulating layer; 6 - geotextiles; 7 - bearing layer; 8 - a layer of sand; 9 - soil-vegetation layer; 10 - grass; 11 - overflow; 12 - water supply; 13 - regulatory capacity; 14 - fixed water level; 15 - supply of water to the installation; 16 - rain simulation container; 17 - removable frame; 18 - removable pallet; 19 - shield of piezometers; 20 - piezometric tubes

To provide the process of flooding the infiltration basin surface, a model solution of rainwater with a flow $q \geq 80 \mathrm{ml} / \mathrm{s}$, corresponding to the intensity of $i_{f l} \geq 20 \mathrm{~mm} / \mathrm{min}$ and $Q_{s u p} \geq 80 \mathrm{ml} / \mathrm{s}$ $(4,81 / \mathrm{min})$, was supplied to the unit. Their indication was made before the experiment beginning, during beginning, in the middle and at the end of each experiment. 
The container 16 with holes $1 \mathrm{~mm}$ in diameter, located in a $30 \mathrm{~mm}$ step, $630 \times 430 \times 200 \mathrm{~mm}$ in size, provided simulation of the rainfall on installation. The water supply to the installation was carried out through the tube 15, and the constant level 14 was provided in the capacity of controlling the flow rates 13 with the overflow tube 11 . Between the container 16 and the surface of the cover there is a removable tray 18 to provide the required rain intensity to the water supply for loading the plant. Water level marks were fixed on a scale 19 with piezometric tubes 20. Drainage water was discharged via a tube 3 where a crane was installed to adjust the required flow. Starting from the sond minute of the experiment, a layer of runoff was formed on the surface of the site. It indicates the beginning of the flooding process, and the formation of drainage.

It was determined that air is in the open-graded sub-base pores of the infiltration basin, and the flooding of the surface of the basin with water prevents free aeration. There was a need to study the infiltration of rainwater into the basin with different deaerating options (under the same input conditions and preparatory stages):

a) with the forced removal of air through the tubes 2 and 3 of the piezometers shield (removal of air bubbles from U-shaped bends of tubes with rubber pear);

b) with free aeration of the 2 and 3 tubes of the piezometers shield;

c) without removing air («pushing» air bubbles from the U-shaped bends of tubes 2 and 3 in the middle of sub-base of the experiment rig with a rubber pear filled with water).

The results of the research. The obtained results of the filling process of the basin correspond to the previously obtained analytical dependence [7, ф. (3.15)]:

$$
Q_{d r}=k_{\text {meas }} \cdot i_{a r} \cdot F_{a r} \cdot\left(1-e^{-\varepsilon \cdot t}\right) \text {, }
$$

where $k_{\text {meas }}$ - coefficient, which takes into account units of measurement of output parameters;

$i_{a r}$ - intensity of rainwater inflow to cover infiltration basin (areas);

$F_{a r}$ - the area of coverage of the infiltration area;

$t$ - duration of infiltration;

$\varepsilon$ - the degree of power that is calculated with the formula:

$$
\varepsilon=\frac{k_{e} \cdot K_{f}}{p \cdot H}
$$

where $k_{e}$ - a coefficient of equivalence taking into account the conditions and parameters of drainage (determined experimentally);

$K_{f}, p$ i $H$ - a filtration coefficient, porosity and height base.

Graphs of changes in drainage discharges from the infiltrate duration obtained by experimentally and according to formula (3) is shown in Fig. 2, and it takes into account the water infiltration features during flooding of the infiltration basin:

$$
Q_{d r}=k_{\text {meas }} \cdot k_{p r} \cdot Q_{\text {sup }} \cdot\left(1-e^{-\varepsilon \cdot\left(t-t_{d}\right)}\right)
$$

where $k_{p r}$ - a coefficient that takes into account the proportion of water filtered through the basin to water flew on surface and is determined with the formula (4);

$Q_{\text {sup }}$ - a water discharge to the experimental rig;

$t_{d}$ - duration of drainage water outflow from the beginning of infiltration.

$$
k_{z}=\frac{Q_{\text {inf }}}{Q_{\text {sup }}}
$$

де $Q_{\text {inf }}$ - an infiltration discharge through the base course (in fact, it is the expense of $Q_{o}$ in formula (6)) (Fig. 6).

The numerical values of the obtained coefficients and other parameters are given in the Table 1 . So, as in formula (3) the measurements of water flow $Q_{s u p}$ and $Q_{d r}$ are the same, $\mathrm{ml} / \mathrm{s}$, coefficient $k_{\text {meas }}=1.0$. Coefficient $k_{p r}$ was determined with the formula (4), and $k_{e}$ and parameter $t_{d}-$ were calculated by calculating the maximum approximation of theoretical curves to experimental data. 


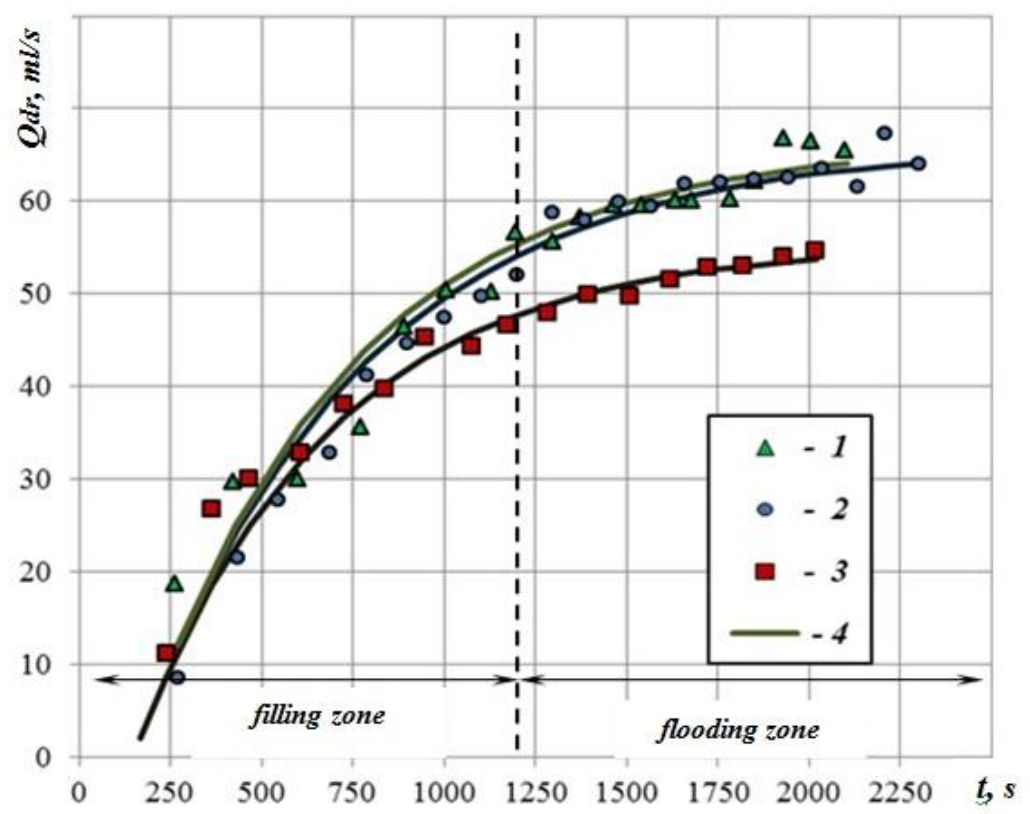

Fig. 2. Graph of drainage discharges change from the duration of infiltration when filling the infiltration basin:

1 - experimental data with forced aeration removal process from the base;

2 - also, with natural aeration removal; 3 -also, non-aeration process; 4 -theoretical curves

Table 1 - Values of coefficients and dependency parameters (3) for different air removal options

\begin{tabular}{|c|c|c|c|}
\hline $\begin{array}{c}\text { Coefficients and } \\
\text { parameters }\end{array}$ & $\begin{array}{c}\text { Forced aeration } \\
\text { removal process }\end{array}$ & $\begin{array}{c}\text { Natural } \\
\text { aeration } \\
\text { removal }\end{array}$ & $\begin{array}{c}\text { Non-aeration } \\
\text { process }\end{array}$ \\
\hline$k_{\text {meas }}$ & 1.0 & 1,0 & 1.0 \\
\hline$k_{e}$ & 0.18 & 0.19 & 0.21 \\
\hline$K_{f}, \mathrm{~mm} / \mathrm{s}$ & 1.27 & 1.15 & 1.21 \\
\hline$\varepsilon, \mathrm{s}^{-1}$ & 0.00169 & 0.00161 & 0.00189 \\
\hline$t_{d}, \mathrm{~s}$ & 150 & 150 & 150 \\
\hline$Q_{\text {sup }}, \mathrm{ml} / \mathrm{s}$ & 86.34 & 86.42 & 86.46 \\
\hline$Q_{\text {inf }}, \mathrm{ml} / \mathrm{s}$ & 66.54 & 66.09 & 55.56 \\
\hline$k_{p r}$ & 0.77 & 0.765 & 0.64 \\
\hline
\end{tabular}

The data of Fig. 2 show that in the cases of forced aeration removal process and free aeration removal from the base of installation, experimental data and theoretical curves coincide. If the air was not removed from sub-base layers, drainage water discharges were lower than when air was removed (under the same conditions of supply and water diversion). This can be explained with the fact that in the latter case, jammed in the sub-base air went through the upper layer of the base and appeared additional resistance of water infiltration.

The graphs of changes in the water levels in the sub-base layers and over them show that they are almost straightforward and are sufficiently accurately approximated by linear regression equations (Fig. 3). The same dependencies of changes in water levels of time during basin filling and surface flooding are relative in the case of absence of drainage water diversion and their different values. 


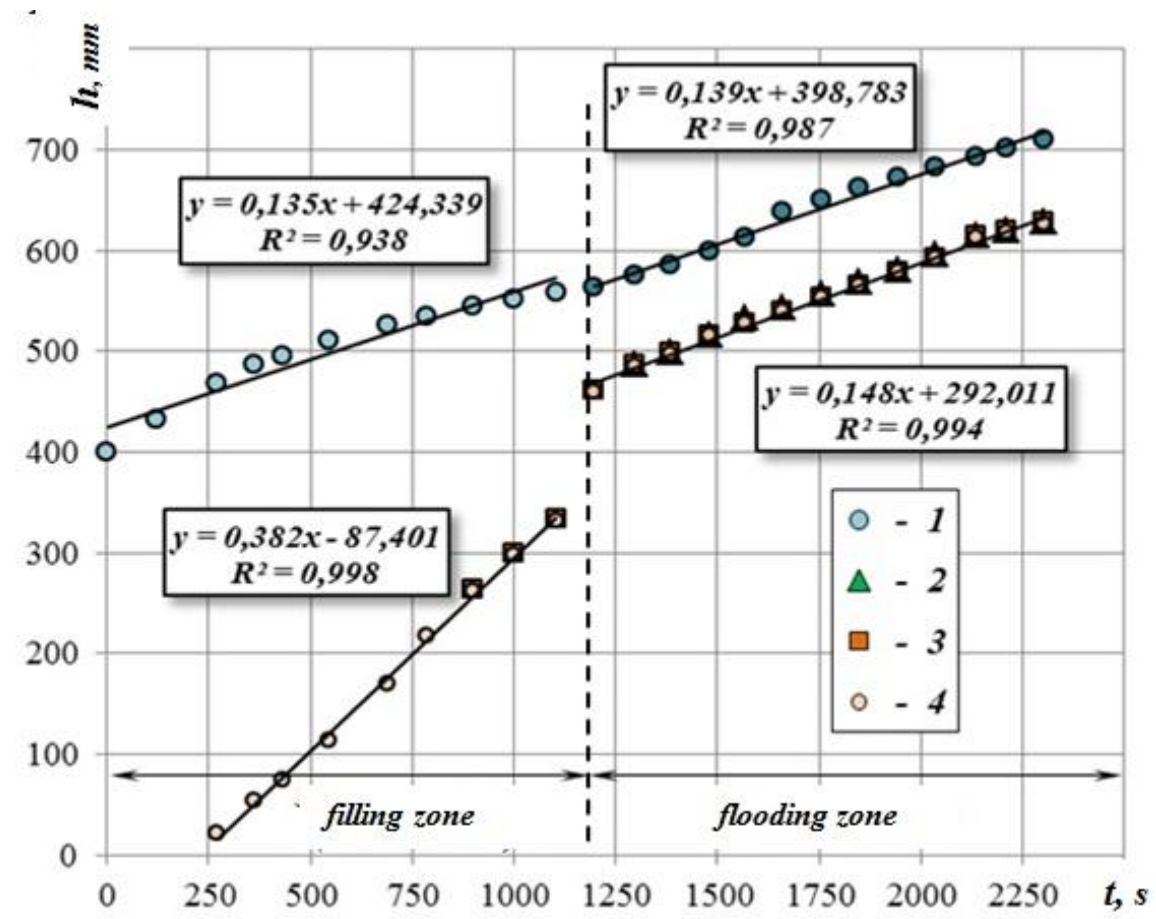

Fig. 3. Graphs of changes in water levels in the sub-base layers with natural aeration removal when filling of infiltration basin:

1 - experimental data on changes in water level above the loading surface; 2,3 i 4 - also, under the upper (plant), holding and accumulating layers

A similar situation of water levels changes in the sub-base layers and over it occurs when the infiltration basin is emptied (Fig. 4). As with its filling there are two zones: flooding (partial water filling of sub-base) and flooding (with full water filling and its accumulation over the surface of the basin).

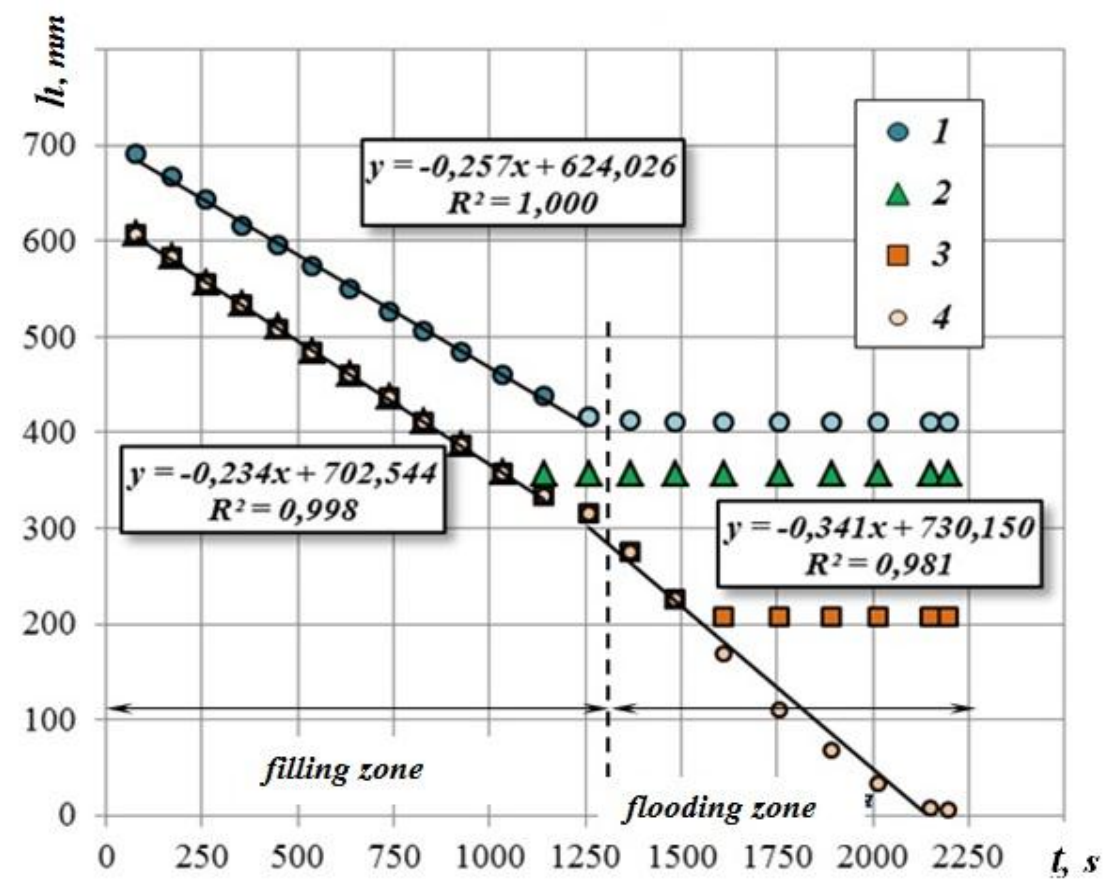

Fig. 4. Graphs of changes in water levels in the sub-base layers from the beginning of emptying of the infiltration basin:

1 - experimental data on changes in water level above the loading surface; 2, 3 and 4 - also, under the upper (plant), holding and accumulating layers 
In both cases (filling and emptying of the basin) in the flood zone, the water levels between the sub-base layers (in the 2, 3 and 4 tubes of the piezometers shield) were practically the same. This means that during water filtration through the basin, the pressure loss almost completely falls on the top layer of the charge and depends on its water permeability and filtration ability.

Changes in drainage discharges of the duration of filtration during emptying of the infiltration basin in each of the zones (flooding and logging) are sufficiently accurately approximated by linear regressive dependencies (Fig. 5). In this case drainage water consumption depends both on the filtration properties of the upper layer and on the hydraulic resistance of the drainage system, including the resistance of the control element at the outlet.

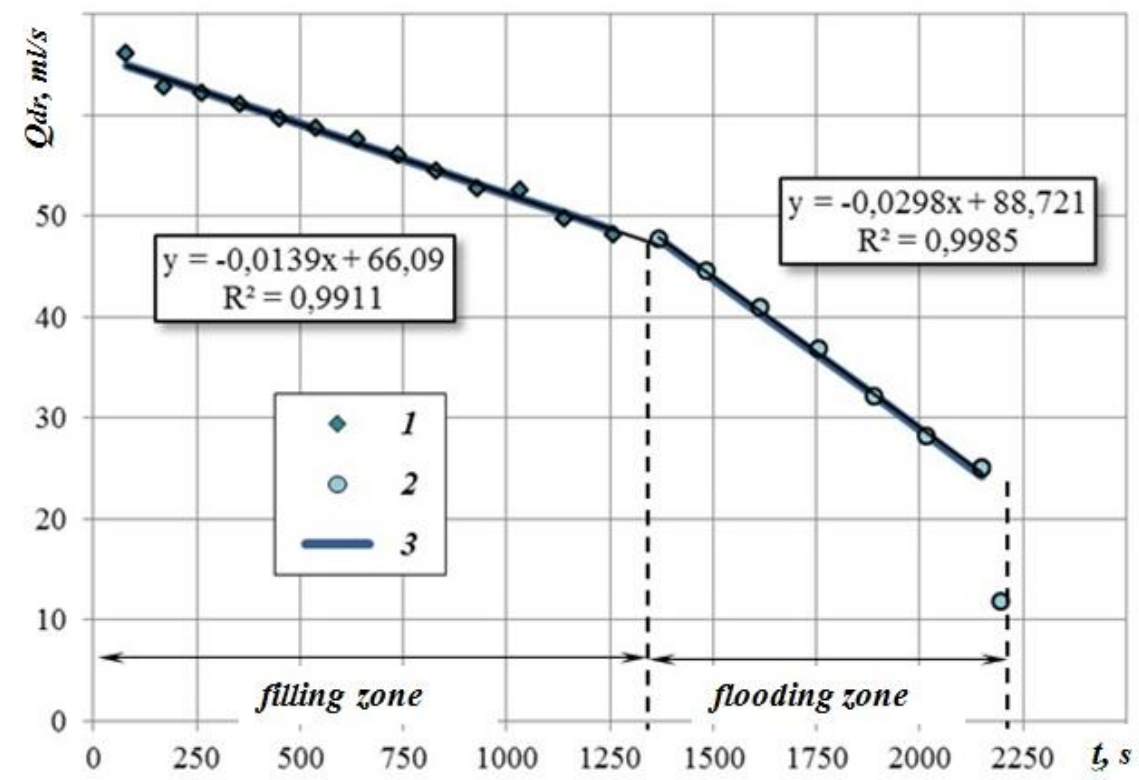

Fig. 5. Graphs of changes in drainage water discharges at the beginning of the infiltration basin fragment emptying:

1 - experimental data for the basin flood zone; 2 - the same for the flood zone (empty sub-base); 3 - theoretical dependences of formulas (5) i (6)

In the filling zone drainage water discharges depend mainly on the hydraulic resistance of the drainage system, especially the resistance of the control element at the outlet of the drainage tube. The dependence of these discharges on the duration of drainage corresponds to the previously obtained analytical dependence [7, ф. (3.23)]:

$$
Q_{d r}=Q_{o . f} \cdot\left(1-b_{f} \cdot\left(t-t_{f l}\right)\right),
$$

where $Q_{o . f}$ - initial a water discharge at time $t_{f l}$ (for conditions of process of the infiltration basin in the flooded state - the start of emptying, i.e the end of the flood zone and the beginning of the fill zone);

$b_{f}$ - parameter depending on the conditions of emptying (determined experimentally).

For the conditions shown in Fig. 5 received: $Q_{o . f}=47.73 \mathrm{ml} / \mathrm{s} ; t_{f l}=1369 \mathrm{~s}(3671-2302)$; according to calculations $-b_{f}=0.000625$ (is calculated for the theoretical duration of complete emptying of the sub-base $T_{\text {emp }}=1600 \mathrm{~s}-b_{f}=1 / T_{\text {emp }}$ [7]).

By analogy with formula (5) for the flood zone for the time from the beginning of emptying:

$$
Q_{d r . f l}=Q_{o . f l} \cdot\left(1-b_{f l} \cdot t\right),
$$

where $Q_{o . f l}$ - initial drainage flow at the time of the end of the arrival storm water on the surface of the infiltration basin and the beginning of its emptying in the flood zone;

$b_{f l}$ - parameter depending on the conditions of emptying in the flood zone.

The initial drainage flow $Q_{o . f l}$ during emptying the infiltration basin (installation rig) is equal to its maximum drainage flow $Q_{d r \text {, max }}$ which is calculated with the formula (3) at the time of the rainwater 
end $t_{r . w}$ of drainage flow to the surface of the basin (installation rig). For the conditions shown in Fig. 5, there is obtained: $Q_{o f l}=66.08 \mathrm{ml} / \mathrm{s} ; b_{3}=0.00021$ (calculated for the theoretical duration of complete emptying of the infiltration basin $\left.T_{e m p}=4760 \mathrm{~s}-b_{f l}=1 / T_{e m p}\right)$. Based on the experimental data the process of the infiltration basin emptying can be illustrated with a graph (Fig. 6).

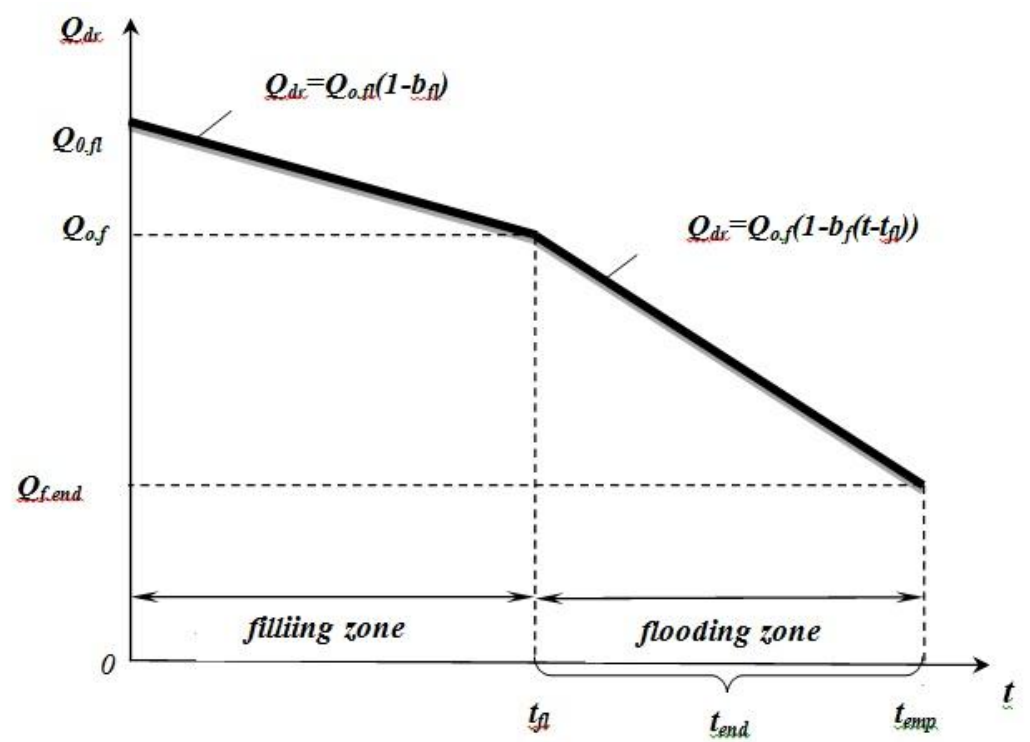

Fig. 6. Schematic graph of changes in drainage water consumption when emptying of infiltration basin

Taking into account the volumes of water located in the $W_{f l}$ flood zones and the $W_{f}$ filling at the beginning emptying of the basin, at value $Q_{o . f}=Q_{d r . f l}$ from the formula (6) at $t=t_{f l}$ and $Q_{\text {fend }}=$ $Q_{d r}$ from the formula (5) at $t=t_{e m p}$, dependencies are obtained to determine the parameters $b_{f l}$ and $t_{f l}$ for the flooding zone; $b_{f}$ and $t_{f}$ - for the fill zone:

$$
\begin{array}{cc}
t_{f l}=\frac{2 \cdot F \cdot h_{w}}{Q_{o . f l}+Q_{o . f}}=\frac{h_{w}}{\bar{V}_{f l}} ; & t_{f}=\frac{2 \cdot F \cdot H \cdot p}{Q_{o . f}+Q_{f . k}}=\frac{H \cdot p}{\bar{V}_{f}} ; \\
b_{f l}=\frac{V_{o . f l}}{2 \cdot h_{w}} \cdot\left(1-\left(\frac{V_{o . f}}{V_{o . f l}}\right)^{2}\right) ; & b_{f}=\frac{V_{o . f}}{2 \cdot H \cdot p} \cdot\left(1-\left(\frac{V_{f . \text { end }}}{V_{o . f}}\right)^{2}\right),
\end{array}
$$

where $\bar{V}_{f l}, V_{o . f l}$ i $V_{o . f}$ - water penetration rates, respectively, average, at the beginning and at the end of the flood zone (the beginning of the fill zone);

$\bar{V}_{f}, V_{o . f} \mathrm{i} V_{f . e n d}$ - water penetration rates, respectively, average, at the beginning and at the end of the flood zone;

$Q_{o f f}$ i $Q_{o . f}$ - initial drainage a water discharge at the beginning of flooding and filling zones (see formulas (5) and (6) and fig. 6);

$h_{w}$ - height of the water layer above the load (in the flood zone);

$F, H$ i $p$ - area, height and porosity of basin sub-base.

Calculated values of the parameters $b_{f l}, t_{f l}, b_{f}$ and $t_{f}$ determined from experimental data are shown in the Table. 2. They confirm the admissibility of the application of formulas (7) and (8) for practical engineering calculations. The verification of the parameters calculated values correspondence experimentally showed that these formulas are quite suitable for practical engineering calculations. Based on the analysis of the experimental data obtained for practical engineering calculations, the following additional dependencies between the parameters of formulas (5) and (6) can be recommended:

$$
V_{o . f} \cong 0.8 \cdot V_{o . f l} ; \quad b_{f} \cong b_{f l} / p .
$$


Table 2 - Results of calculations of the parameters of formulas (5) - (8) according to experimental data

\begin{tabular}{|c|c|c|c|c|c|c|c|c|}
\hline \multirow{2}{*}{$\begin{array}{l}\text { Exp } \\
\text { erim } \\
\text { ent } \\
\text { No. }\end{array}$} & \multicolumn{3}{|c|}{$\begin{array}{c}\text { Water penetration rates, } \\
\mathrm{mm} / \mathrm{s}\end{array}$} & \multirow{2}{*}{$\begin{array}{l}h_{w} \\
\mathrm{~mm}\end{array}$} & \multicolumn{4}{|c|}{ Parameters } \\
\hline & $V_{o . f l}$ & $V_{o . f}$ & $V_{f . e n d}$ & & $b_{f l}$ & $t_{f l}$ & $b_{f}$ & $t_{f}$ \\
\hline 1 & 0.601 & 0.488 & 0.122 & 272 & $\frac{0.000479}{0.000410}$ & $\frac{456}{499}$ & $\frac{0.001544}{0.001701}$ & $\frac{486}{439}$ \\
\hline 2 & 0.447 & 0.340 & 0.109 & 304 & $\underline{0.000346}$ & $\frac{750}{772}$ & $\underline{0.001064}$ & $\frac{638}{596}$ \\
\hline 3 & 0.248 & 0.189 & 0.063 & 324 & $\underline{0.000168}$ & $\frac{1380}{1484}$ & $\underline{0.000553}$ & $\frac{1201}{1063}$ \\
\hline 4 & 0.277 & 0.240 & 0.110 & 176 & $\underline{0.000218}$ & $\frac{723}{680}$ & $\underline{0.000553}$ & $\frac{984}{766}$ \\
\hline 5 & 0.275 & 0.202 & 0.095 & 290 & $\underline{0.000210}$ & $\frac{1320}{1214}$ & $\underline{0.000603}$ & $\frac{880}{901}$ \\
\hline
\end{tabular}

Note: The numerator is given values obtained by experimental data, and in the denominator - by formulas (7) and (8).

The obtained data show that the velocity rates, as well as the filtration coefficients, the subbase of infiltration basins with the typical upper plant layer depend not only on their structural dimensions (height of the layers of sub-base, types of soils and their open-graded composition, etc.) They also depend on the state of surface pavement (development of the plants root system, the degree of clogging). As a result of experimental studies, it was found that the penetration rates of infiltration basins with a typical vegetative top layer were $V_{p}=0.1-0.5 \mathrm{~mm} / \mathrm{s}$, and the filtration coefficients of this upper layer were $K_{f . t l}=0.16-0.36 \mathrm{~mm} / \mathrm{s}$.

Conclusion. As a result of experimental studies of a fragment of an infiltration basin with a typical vegetative upper layer, a mathematical model of its filling and emptying processes for a flooded state has been specified. The ranges of the main parameters of the refined model are determined and the analytical dependences for their calculations are obtained. It has been established that the operating modes of such basins depend on the filtration properties of the upper layer of loading, the method of removing the air from the loading and the conditions for the selection of drainage water. Experimentally it was found that the velocity rates of the vegetation top layer are $0.1-0.5 \mathrm{~mm} / \mathrm{s}$, and the filtration coefficients are $0.16-0.36 \mathrm{~mm} / \mathrm{s}$.

The obtained experimental results show that the duration of infiltration basins emptying depends on the parameters of sub-base of basins and conditions of emptying, on which the value of drainage discharge depends on the beginning of its emptying. The value of this discharge is important not only for determining the parameters and operating modes of each infiltration basin, but also for hydraulic calculations of the joint operation of the structures of rainwater drainage. The values of these discharges depend on both the parameters of the infiltration basins and the conditions for controlling drainage discharges. Therefore, further research is focused on the evaluation of these parameters and their interconnections.

\section{References}

[1] V.M. Zhuk, "Suchasni systemy upravlinnya doshchovym stokom na zabudovanykh terytoriyakh", Problemy vodopostachannya, vodovidvedennya ta hidravliky: Naukovotekhnichnyy zbirnyk, Kyiv, no. 17, pp. 26-31, 2011.

[2] V.M. Zhuk, I.Z. Kachmar, "Teoretychnyy rozrakhunok nakopychennya doshchovoho stoku na poverkhni udoskonalenykh pokryttiv", Visnyk $N U$ "L'vivs'ka politekhnika". Teoriya $i$ praktyka budivnytstva, L'viv, no. 520, pp. 122 - 128, 2015.

[3] I.YU. Popadyuk, Metody hidravlichnoho rozrakhunku bahatosektsiynykh rehulyuval'nykh rezervuariv doshchovykh stichnykh vod: avtoref. dys. ... kand. tekhn. nauk: 05.23.16. Rivne, 
2012.

[4] O.A. Tkachuk, O.V. Shevchuk, "Efektyvnist' zastosuvannya vodopronyknykh pokryttiv dlya upravlinnya doshchovymy stokamy na zabudovanykh mis'kykh terytoriyakh", Visnyk ODABA, Odesa: Optimum, Vol. 59, pp. 235-242, 2015.

[5] O.A. Tkachuk, O.V. Shevchuk, "Infil'tratsiyni maydanchyky yak suchasnyy metod rehulyuvannya doshchovoho stoku pry blahoustroyi mis'kykh terytoriy", Naukovotekhnichnyy zbirnyk «Mistobuduvannya ta terytorial'ne planuvannya», Kyiv: KNUBA, no. 59, pp. 437-442, 2016.

[6] O.A. Tkachuk, YA.V. Yaruta, "Ochyshchennya doshchovoho stoku pry yoho rehulyuvanni za dopomohoyu infil'tratsiynykh baseyniv", Naukovyy visnyk budivnytstva, Kharkiv: KHNUBA, Tom 95, no. 1, pp. 204-211, 2019.

[7] O.V. Shevchuk, Obgruntuvannya rozrakhunkovykh parametriv infil'tratsiynykh maydanchykiv u mis'kykh systemakh doshchovoho vodovidvedennya. dyser. kand. tekhn. nauk.: 05.23.04: Rivne, 2017.

[8] YA.V. Yaruta, "Vykorystannya infil'tratsiynykh metodiv rehulyuvannya doshchovoho stoku na mis'kykh terytoriyakh v suchasnykh umovakh", Mistobuduvannya ta terytorial'ne planuvannya. Nauk. tekhn. zb., Kyyiv: KNUBA, Vol. 67, pp. 539-545, 2018.

[9] Queensland Urban Drainage Manual. The State of Queensland (Department of Energy and Water Supply); Brisbane City Council; Institute of Public Works Engineering Australia, Queensland Division Ltd, 2013.

[10] Tarboton D.G. Rainfall-Runoff Processes. Utah State University: Logan, UT. USA, 2003.

[11] Virginia DCR stormwater design, Specification No. 7. Permeable Pavement . Virginia, 2011. Version 1.8.

\title{
ДОСЛІДЖЕННЯ ПРОЦЕСІВ НАПОВНЕННЯ, ЗАТОПЛЕННЯ ТА СПОРОЖНЕННЯ ІНФІЛЬТРАЦЙНИХ БАСЕЙНІВ
}

\author{
Ткачук О.А. Д.т.н., професор, \\ o.a.tkachuk@nuwm.edu.ua; ORCID: 0000-0002-3036-0010 \\ Ярута Я.В. аспірант, \\ ORCID: 0000-0001-9291-7710 \\ Шевчук О.В. к.т.н., асистент, \\ ORCID: 0000-0002-7403-8314
}

Національний університет водного господарства та природокористування

\begin{abstract}
Анотація. Показано, що інфільтраційні басейни, які виконують роль регулювальнофільтрувальних споруд в системах дощового водовідведення, можуть працювати як в підтопленому, так і затопленому режимах. В результаті експериментальних досліджень фрагмента інфільтраційного басейну з типовим рослинним верхнім шаром встановлено, що при заповненні та спорожнення басейнів втрати напору практично повністю припадають на верхній шар завантаження, а тривалість їх спорожнення залежить від параметрів завантаження басейнів і умов їх спорожнення. Отримано графіки зміни рівнів води в шарах завантаження і визначено, що вони залежать від способу видалення повітря з завантаження та умов відбору дренажних вод. Уточнена математична модель процесів наповнення i спорожнення інфільтраційних басейнів в затопленому режимі, визначені діапазони змін ії додаткових параметрів і отримано аналітичні залежності для їх розрахунків. Встановлено, що режими наповнення і спорожнення інфільтраційних басейнів, в основному, залежать від фільтраційних властивостей верхнього шару завантаження, способу видалення повітря 3 завантаження та умов відбору дренажних вод. Для інфільтраційних басейнів 3 типовим рослинним верхнім шаром експериментально отримано, що його коефіцієнти фільтрації становлять 0,16-0,36 мм/с, а швидкість водопроникнення - 0,1-0,5 мм/с.

Експериментальні результати показують, що тривалість спорожнення інфільтраційних
\end{abstract}


басейнів залежить від параметрів завантаження басейнів i умов їх спорожнення, які визначаються отриманими параметрами, зокрема, величиною початкової дренажної витрати на початку його спорожнення. Вона залежить від умов відбору дренажних витрат конкретного інфільтраційного басейну. Значення цієї витрати важливе не тільки для визначення параметрів і режимів роботи кожного інфільтраційного басейну, а й для гідравлічних розрахунків сумісної роботи споруд дощового водовідведення. Тому, подальші дослідження орієнтовані на ці параметри і їх взаємозв'язок.

Ключові слова: водовідведення, регулювання дощового стоку, інфільтраційний басейн, затоплення, підтоплення, фільтрація.

\title{
ИССЛЕДОВАНИЕ ПРОЦЕССОВ НАПОЛНЕНИЯ, ЗАТОПЛЕНИЯ И ОПОРОЖНЕНИЯ ИНФИЛЬТРАЦИОННЫХ БАССЕЙНОВ
}

\author{
Ткачук А.А., д.т.н., профессор, \\ o.a.tkachuk@nuwm.edu.ua, ORCID: 0000-0002-3036-0010 \\ Ярута Я.В., аспирант, \\ ORCID: 0000-0001-9291-7710 \\ Шевчук О.В. к.Т.Н., ассистент, \\ ORCID: 0000-0002-7403-8314 \\ Национальный университет водного хозяйства и природопользования
}

\begin{abstract}
Аннотация. Показано, что инфильтрационные бассейны, которые выполняют роль регулировочно-фильтровальных сооружений в системах дождевого водоотвода, могут работать как в подтопленном, так и затопленном режимах. В результате экспериментальных исследований фрагмента инфильтрационного бассейна с типичным растительным верхним слоем установлено, что при заполнении и опорожнении бассейнов потери напора практически полностью припадает на верхний слой загрузки, а продолжительность их опорожнения зависит от параметров загрузки бассейнов и условий их опорожнения. Получены графики изменения уровней воды в слоях загрузки и определено, что они зависят от способа удаления воздуха из загрузки и условий отбора дренажных вод. Уточнена математическая модель процессов наполнения и опорожнения инфильтрационных бассейнов в затопленном режиме, определены диапазоны изменений ее дополнительных параметров и получены аналитические зависимости для их расчетов. Установлено, что режимы наполнения и опорожнения инфильтрационных бассейнов, в основном, зависят от фильтрационных свойств верхнего слоя загрузки, способа удаления воздуха из загрузки и условий отбора дренажных вод. Для инфильтрационных бассейнов с типичным растительным верхним слоем экспериментально получено, что его коэффициенты фильтрации составляют 0,16-0,36 мм/с, а скорости водопроникновения - 0,1-0,5 мм/с.

Экспериментальные результаты показывают, что продолжительность опорожнения инфильтрационных бассейнов зависит от параметров загрузки бассейнов и условий их опорожнения, которые определяются полученными параметрами, в частности, величиной начального дренажного расхода в начале его опорожнения. Она зависит от условий отбора дренажных расходов конкретного инфильтрационного бассейна. Значение этого расхода важно не только для определения параметров и режимов работы каждого инфильтрационного бассейна, но и для гидравлических расчетов совместной работы сооружений дождевого водоотвода. Поэтому, дальнейшие исследования ориентированы на эти параметры и их взаимосвязи.
\end{abstract}

Ключевые слова: водоотведение, регулирования дождевого стока, инфильтрационный бассейн, затопления, подтопление, фильтрация.

Стаття надійшла 8.04.2019 